GLOBAL JOURNAL OF PURE AND APDLIED SCIENCES VOL. 14, NO. 1, 2008: 13 - 17

COPYRIGHT (C) BACHUDO SCIENCES CO. LTD. PRINTED IN NIGERIA, ISSN 1118-0579

\title{
PRODUCTION FUNCTION ANALYSIS OF CASSAVA SOLE CROPPING SYSTEMS IN AKWA IBOM STATE, NIGERIA
}

\author{
I. B. ADINYA, O. O. KUYE, M. U. AWOKE, S. AJAYI, D. I. AGOM, \\ I. E. ELE, K. I. OGBONNA, S. O. AKPET AND O. A. AGBA \\ (Received 23 May 2007; Revision Accepted 12 July 2007)
}

\begin{abstract}
An analysis of production function of cassava sole cropping system in Akwa bom State is the main focus of this paper. A lotal of 150 cassava farmers were randomly selected from Uyo Agricultural Zone of Akwa lbom State, using a semi structured questionnaires. Random sampling procedure was used in selecting the respondents in the study area. Multiple regression analysis model was the main tool of data analysis where different functions were tried. Results showed that Cobb-Douglass (double- $\mathrm{log}$ ) production function had the best fit in explaining the relationship between output and inputs used, the coefficient of multiple determinant $\left(R^{2}=0.94\right)$ indicates that ninety four percent of the variability in output of cassava is explained by the independent variables. The F-ratio of 209.77 indicates the overall significance of the model at $1 \%$ level. The production function analysis revealed that fertilizer and labour were inefficiently used. The marginal value products of fertilizer, cassava stem, labour and other operating expenses were $\mathrm{N} 37.40, \mathrm{~N} 108.33$, N217.66 and $\mathrm{N} 106.30$ respectively, there existed allocative inefficiency. There is a high potential for farmers to increase their yields and income by improving on production efficiency and adopting new technologies. It is therefore recommended that extension agents should train farmers on the adoption of new technologies
\end{abstract}

KEYWORDS: Allocative efficiency, production function analysis, cassava sole cropping system, Akwa Ibom State.

\section{INTRODUCTION}

Agricultural system in Akwa Ibom State, whether mono or multiple cropping system has been traditional in nature and mainly concentrated in the hands of peasants or small-holder farmers. According to Awoke and Obeta (1998), these smallholder farmers are those whose production capacity falls between 0.5 and 5 hectares per season. They constitute the majority of the farming population and cultivate mostly the backyard land. In the past, small-holder farmers in Akwa Ibom State are mostly multiple croppers whose population constitute about $85 \%$ of the farming system but the trend is gradually changing because recent agricultural researches have been largely confined to improving sole crop performance through increased population, seed rate, seed depth and planting date. However, extension service has help to encourage sole cropping. Ogungbile and Sann (1991) revealed that in spite of much extension services to encourage sole cropping, a large proportion of land in some parts of Nigeria are devoted to intercropping. According to Herbert, (2005) the challenges of meeting the demand for cassava and other food crops which are highly consumed depends on the knowledge of effectiveness of the utilization of human and material resources. This is important because of the increasing level of competition for scarce resources.

In general, resource use or allocative efficiency in developing countries such as Nigeria may be said to be faced with the problem of under capacity utilization which is associated with low returns, for example, Alimba and Ezinwa (2001), observed that resource allocation under the existing traditional system of farming in Eastern Nigeria is inefficient. Efficient utilization of productive resources may be affected by factors such as government policies, customs and institutions or cultural configuration, cost structures, resource management, ownership patterns and policies, resource administration and services(Upton, 1976; Nweke and Winch( 1979). The rapid increase in population has led to increasing demand for food. Nigeria's population growth rate is put at 2.8 percent per anmum, where as food production declines to below 2.5 percent per annum (Nsikak- Abasi,et al, 2005). With the problem of high population growth rate in Nigeria of about $2.8 \%$ and the shrinking farm size per head, an agricultural boost is required to improve land productivity and generate extra funds for investment, which will have a positive multiplier effect on the rural economy (Delgado et al, 1994). Some of the tools available to provide this boost include efficient use of resources.

Efficiency could be measured from a production function or profit function approach. Efficiency of production is a very importan factor for productivity growth especially in areas where resources are meager as in Nigeria. Efficiency of production is achieved through optimal resource allocation such that more output is achieved with same resource level or the same level of output is achieved using fewer resources. Production function gives the possible output

that can be produced from given quantities of a set of inputs (resources) and their quantities can be varied to obtain optimal output. In carrying out economic analyses, production function provides the basis of decision- making for farmers.

Economic theory identifies three important production efficiency(Farrel, 1984). These include allocative, technical and economic efficiency. Allocative efficiency is the ability of the farmer to use the inputs in optimal proportions given their respective prices and the production technology. Technical efficiency is the measure of the farms success in producing

I. B. Adinya, Department of Agricultural Economics /Extension Cross River University of Tech., Obubra CAMPUS, Nigeria.

O. O. Kuye, Department of Agricultural Economics /Extension Cross River University of Tech., Obubra CAMPUS, Nigeria.

M. U. Awoke, Department of Agricultural Economics, Management and Extension, Ebonyi State University Abakaliki, Nigeria

S. Ajayi, Department of Forestry and Wildlife, Cross River University of Technology, Obubra Campus, Nigeria

D. I Agom, Department of Agricultural Economics/Extension University of Calabar,Calabar, Nigeria.

I. E. Ele, Department of Agricultural Economics/Extension University of Calabar, Calabar, Nigeria.

K. I. Ogbonna, Department of Agricultural Economics/Extension University of Calabar, Calabar, Nigeria.

5. O. Akpet, Department of Animal Science and Fisheries Cross River University of Technology, Obubra Campus

O. A. Agba, Department of Agronomy, Cross River University of Technology, Obubra Campus, Nigeria. 
maximum output from a given set of resources (inputs) i.e. ability to operate on the production frontier (Farrel, 1984).

Economic efficiency is the product of the technical efficiency and allocative efficiency. There is evidence that farmers in developing countrins fail to exploit fully the potential of resources and make allocative errors with result that yields varies widely between farms in Nigeria

Several studies have shown that resources are not efficiently utilized by farmers in Nigeria (Nweke and Winch, 1979; Farrel, 1984; Awoke and Obeta, 1998, Alimba and Ezinwa,2001; Nsikak-Abasi et al,2005;Adinya,2001;Adinya et al, 2006). Therefore, having established the obvious fact that resources are not efficiently utilized in agricultural production in Akwa loom State, it is the aim of this study to examine critically the problems of resource use in sole cassava cropping by small-scale farmers. Utimately, it is hoped that the study will help to bridge the gap between resources availability and efficient utilization in the sole cropping system in Akwa lbom State.

This paper tried to provide some useful information in policies towards increasing cassava production in Nigeria. The study therefore analysed the production function, costs and returns in cassava production under sole cropping and also examined resource use efficiency pattern in cassava production.

\section{ECONOMIC IMPORTANCE OF CASSAVA}

In Nigeria, the selling of cassava products is a thriving business that provides employment to hundreds of people. It provides an important source of livelinood for the middlemen and also provides foreign exchange earnings. The

marketing of cassava chips, as an internationally traded commodity finds its place in the market because of its competitive nutritional value/price structure relative to cereals (Aboje, 2006).

Nigeria is the largest producer of cassava in the world but certainly not the largest exporter of cassava products. If is on record that Nigeria produces the best quality of cassava, about 80 per cent of the total world production while supplies to international market from Nigeria has been small in-spite of our huge production and consumes the largest quantity of the commodity as food more than any other country on the surface of the earth (Aboje, 2006).

Globally, only 14 per cent of the total production of eassava is exported with Thailand being the major exporter Cassava and its derivative has been removed from the Nigeria's export prohibition lists in 1996. Its export is now encouraged among other food crops for which Nigeria is major producer. The direction of cassava export is mainly Europe and North America with European Union accounting for about 30 per cent. Cassava production globally is used for starches and other industrial products and only less than one per cent is processed into ethanol particularly in Brazil (Aboje, 2006)

Cassava is a root tuber crop used as staple food in Nigeria and Africa generally. It is also used for industrial starch, ethanol and in trie production of cassava powder (garri) and chips/ pellets (Aboje, 2006)

According to Adinya, (2001), cassava is widely processed into garri, fufu, or tapioca while the sweet variety [4(2)] called panya is boiled and sliced into smaller size and eaten with soup or coconut or groundnuts. The tubers are also boiled and fed to pigs, its leaves are rich in oils, minerals, vitamin $C$ and proteins

In Ibiaragidi in Bekwarra Local Government Area of Cross River State, it is used as vegetable soup. The leaves are also relished by all classes of livestock. The Chinese are the current major importer of Nigeria cassava chips for animal feed industries. The other buyers of cassava products in the European Union are Netherlands, accounting for over 40 percent of total European Union imports. Germany imports about 20 per cent, while Belgium and Luxembourg about 13 per cent. France 8 per cent, United Kingdom 10 per cent and lialy 2 per cent imports in that order (Aboje, 2006) According to Duff (1994) cassava is one of the staple lood items in Nigeria and has contributed in one way or the other to the economic development of Akwa Ibom State and Nigeria in general.

To increase productivity, sound macro and micro-economic farm policies are needed. These require knowledge of aggregate fam level resource availability and the differences in productivities of these resources in different areas (Chikwendu andAmos, 1998)

\section{METHODOLOGY}

\section{STUOY AREA ANO DATA COLLETION}

The study was carried out in Uyo Agriculural zone of Akwa bom state. The area covers about 304,769 square kilometers and lies on latitude $0532 \mathrm{~N}$ and lonoitude $0756^{\prime} \mathrm{E}$. It has an annual rainfall of about $2000 \mathrm{~m}-30000 \mathrm{~mm}$ it is bordered on the south by lbesikpo and Nsit Ibom Local Government areas, on the west by Abak Local Govemment Area, on the north by ikono and itu Local Government Areas and on the East by Uruan Local Government Area (Uyo Local Government Area Information Brochure. 1992). The area comprise 75 villages with 4 clans namely: Etoi, lkono, Oku and Offot.

Farming and other agro-based activities dominate the economic life of the people in the study area. Food crops commonly cultivated in the area include cassava. maize. yam, cocoyam, plantain, banana and vegetables

Both primary and secondary sources of data were used. The secondary source of data include Review of Annual Reports, books census data, Journals, statistical documents The primary source of data were mainly from field Survey using a set of structured questionnaire. The small-scale cassava farmers in Uyo Agricultural Zone constituted the study population. A multi-stage random sampling procedure was used in the study to draw up a representative sample for the study. At first stage 10 villages were taken from 75 villages. For better coverage in the study area, a sample of 5 farming communities were selected from each of the 10 villages. Three farm families were randomly selected from each of the 50 selected farming communities. In all, 150 farmers were drawn from 50 farming communities in Uyo Agricultural Zone.

\section{METHOD OF ANALYSIS}

The analytical tools used include budgeting technique, descriptive statistics and production furction analysis. Farm budgeting technique was used to estimate the costs and returns of cassava production by farmers. To derive the marginal product of basic cassava production inputs for 2006 cropping season. Cassava production function was estimated using (OLS)

The implicit form of the of the model is presented thus;

$$
Y=F\left(X_{1}, X_{2}, X_{3}, X_{4}, U\right)
$$

$$
\begin{aligned}
& \text { Where } Y=\text { output yield of cassava (kg/ha) } \\
& \qquad \begin{aligned}
\left.X_{1}=\text { quantity of ferilizer ( } \mathrm{kg} / \mathrm{ha}\right) \\
X_{2}=\text { quantity of cassava stem (kg/ha) } \\
X_{3}=\text { labour (man-days/ha) } \\
X_{4}=\text { other operating expenses (naira/ha) } \\
U=\text { error term }
\end{aligned}
\end{aligned}
$$

The functional forms fitted are specified below. (a)linear production function

$$
Y=a+b_{1} X_{1}+b_{2} X_{2}+b_{3} X_{3}+b_{4} X_{4}+c \ldots(1)
$$

Where $Y, X_{4}-X_{4}$ are defined in the implicit form 


$$
\begin{aligned}
b_{1}-b_{4} & =\text { regression coefficients of inputs } X_{1}-X_{4} \\
a & =\text { constant term } \\
e & =\text { error term }
\end{aligned}
$$

(b) Semi-log Production function:

$$
\begin{aligned}
Y= & \log a+b_{1} \log X_{1}+b_{2} \log X_{2}+b_{3} \log X_{3} \\
& +b_{4} \log X_{4}+e_{\text {e. }} \text { equation (2) }
\end{aligned}
$$

(c) Cobb-Douglas Production function:

$$
\begin{aligned}
\log Y= & \log a+b_{1} \log X_{1}+b_{2} \log X_{2}+b_{3} \log X_{3}+b_{4} \\
& \log X_{4}+c \ldots \text { equation (3) }
\end{aligned}
$$

Three linear function forms were fitted in the analysis, these are linear, semi-log and Cobb-Douglas (doublelogarithmic) production function forms. However, the CobbDouglas (double- logarithmic function form gave a better fit and therefore was chosen as the lead equation.

The model took the form specified below

$$
\log Y=\log a
$$

$+a_{1 \log X 1}+a_{2 \log X 2}+a_{3 \log X 3}+a_{4 \log X 4}+U$

Where $L o g$ =natural logarithm

$$
\begin{aligned}
& Y=\text { output }(\text { yield ) of cassava( } \mathrm{kg} / \mathrm{ha}) \\
& X_{1}=\text { quantity of fertilizer }(\mathrm{kg} / \mathrm{ha}) \\
& X_{2}=\text { quantity of cassava stem }(\mathrm{kg} / \mathrm{ha}) \\
& \left.X_{3}=\text { labour(man-days } / \mathrm{ha}\right) \\
& X_{4}=\text { other operating expenses(naria/ha) } \\
& U=\text { error term }
\end{aligned}
$$

$a_{1}, a_{2}, a_{3}, a_{4}$ are coefficients of the above variables investigated while $a_{0}$ is the $y$-intercept.

Each resource was measured using the formula: the average physical product (APP)was derived by dividing total output by total inputs i.e.

$A P P=\frac{Y}{X}$

The marginal physical product (MPP) was derived by dividing total output by total inputs. $M P P=\frac{D Y}{D X}$

MPP $\times$ Price of product $=$ marginal value $\operatorname{product}($ MVP $)$. The allocative efficiency of resource was determined by ascertaining whether or not the ratio of the marginal value products to the input price was equals to one
$\frac{M V P}{P}=1$

Where MVP=Marginal Value Product $P=$ Unit Price of Input

The marginal products (MP) were derived by multiplying the average product (AP) by the elasticitiesof production, given that:

$$
\begin{gathered}
M P=A P \times E P \\
E P=\frac{M P}{A P}
\end{gathered}
$$

\section{RESULT AND DISCUSSION}

Table 1 revealed that the per hectare cost of sole cassava was N24,414.80. Human labour was the most predominant cost item. It accounted for $N 15,264.50$ or $62.52 \%$ of the total cost of production process $(N 24,414.80)$. A total of 548.40 man-days was used in sole cassava production. Weeding, harvesting, planting, and land preparation in that order were the most labour intensive, with weeding alone accounting for $27.35 \%$ of the total labour input. Family labour was used for most operations. While hired labour was used only for weeding and land preparation. The sampled farmers did not use herbicides and insecticides. Besides that, the quantity of cassava sterns used (500plants per hectare) in sole cassava production was far below the recommended plant per hectare of (12000 planis per hectare) planted at $90 \mathrm{~cm} \times 90 \mathrm{~cm}$ The effect of this low plant population on the crop performance may include low crop competition with weeds since the crop may not close the canopy. This leads to weed infestation on isolated plant stands and low yields. On the other hand, the amount of fertilizer used $(560 \mathrm{~kg} / \mathrm{ha})$ was compared to the recornmended $(60-120 \mathrm{~kg} / \mathrm{ha})$ of urea, single super phosphorus or about $120 \mathrm{~kg} / \mathrm{ha}$ of compound fertilizer like 15-15-15 (Fertilizer Use and Management Practices for Crops in Nigeria, 1989). Table 1, also shows the returns and yield per hectare of sole cassava production. The mean yield was $6000 \mathrm{~kg}$ or 6 lonnes per hectare. The profit margin obtained with family labour cost was N5,585.20 per hectare. There was a profit N5.585.20 per hectare

From table 2, using three functional forms in the analysis, fertilizer, cassava stems, labour and other cost were the significant determinants (significant at $1 \%$ level) of cassava yield. Table 2 aiso revealed that double-log production function is the lead equation, the coefficients of multipie determinant $\left(R^{2}=0.94\right)$ indicates that ninety four percent of the variability in output of cassava is explained by the independent variable. The F-ratio of 209.77 indicated the overall significance of the model at $1 \%$ level.

Table 3 revealed that the marginal value products of fertilizer. cassava stem, labour and other operating expenses were N37.40, N108.33, N217.66 and N106.30 respectively, there existed allocative inefficiency. Ogunfowora, et al (1974); Osuji (1978) and Emokaro and Erhabor (2005), obtained similar results even though they considered resource inputs in the aggregate. 
Table1: Average Production Costs, Inputs Usage and Returns Per Hectare of Sole Cassava Production

\begin{tabular}{|c|c|c|c|}
\hline Variables & Family Labour Costed & & \\
\hline & Unit Price (A) & Units/ha & Value/ha $(\bar{N})$ \\
\hline 1. Cassava Outputs (co)kg & 1500 & 6000 & 30.000 .00 \\
\hline $\begin{array}{l}\text { 2. Capitals Operating Inputs } \\
\text { - Cassava Stems }(\mathrm{kg})\end{array}$ & 100 & 500 & 2500 \\
\hline - Fertilizers (kg) & 12 & 560 & 2800 \\
\hline - Other Capital operating inputs & 18.5 & & 1850 \\
\hline & & & 7150 \\
\hline $\begin{array}{l}\text { 3. Labour Inputs (Man-days) } \\
\text { - Land Preparation (hired labour) }\end{array}$ & 15 & 76.66 & 2300 \\
\hline - Planting (Family labour) & 20 & 106 & 2120 \\
\hline - Manure application (Family labour) & 20 & 25.49 & \\
\hline - Fertilizer application (Family labour) & 30 & 34 & 1034.8 \\
\hline - Weeding (hired labour) & 37.5 & 150 & 4500.00 \\
\hline - Harvesting (Family labour) & 30 & 144 & 4330.00 \\
\hline $\begin{array}{l}\text { Peeling/Grinding/Pressing/Frying/Bagging } \\
\text { (Family labuor) Total Labour Inputs (TL } 1 \text { ) }\end{array}$ & & 548.40 & \\
\hline $\begin{array}{l}\text { 4. Total Variable Cost (TVC }=\text { TCOC+ } \\
T_{1} \text { ) }\end{array}$ & & & $22,414.8$ \\
\hline $\begin{array}{l}\text { 5. - Fixed Cost Rent on Land } \\
\text { - Depreciation }\end{array}$ & 500 & & $\begin{array}{l}500.00 \\
1500.00\end{array}$ \\
\hline 6. Total Fixed Cost (TFC) & & & $2,000.00$ \\
\hline 7. Total Costs $(T C=T V C+T F C)$ & & & $24,414.80$ \\
\hline 8. Net returns (CO-TC) & & & $5,585.2$ \\
\hline
\end{tabular}

Source: Computed from field Survey, 2007.

\begin{tabular}{|c|c|c|c|c|c|c|c|c|}
\hline $\begin{array}{l}\text { Product- } \\
\text { ion } \\
\text { function } \\
\text { fom }\end{array}$ & Constant & $\begin{array}{l}X_{1} \\
\text { Fertilizer }\end{array}$ & $\begin{array}{l}X_{2} \\
\text { CASSAVA } \\
\text { STEM }\end{array}$ & $\begin{array}{l}X_{3} \\
\text { Labour }\end{array}$ & $\begin{array}{l}X_{4} \\
\text { Operat- } \\
\text { ing expen- } \\
\text { ses }\end{array}$ & $R^{2}$ & ${ }_{R^{2}}^{\text {Adj. }}$ & F-ratio \\
\hline Linear & -39.4871 & $\begin{array}{l}1.0763 \\
(0.2070)\end{array}$ & $\begin{array}{l}3.1335^{\circ} \\
(4.2662)\end{array}$ & $\begin{array}{l}1.7862^{k} \\
(3.9511)\end{array}$ & $\begin{array}{l}3.9008^{\star} \\
(4.6310)\end{array}$ & 0.91 & 0.90 & 203.2960 \\
\hline Semi-log & 2.2092 & $\begin{array}{l}0.0003 \\
(0.17)\end{array}$ & $\begin{array}{l}0.0450 \\
(1.49)\end{array}$ & $\begin{array}{l}0.0157^{*} \\
(3.74)\end{array}$ & $\begin{array}{l}0.0073^{\sharp} \\
(4.78)\end{array}$ & 0.84 & 0.83 & 75.8410 \\
\hline Double-log. & 1.7053 & $\begin{array}{l}0.0744 \\
(2.5630)\end{array}$ & $\begin{array}{l}0.0807 \\
(3.2070)\end{array}$ & $\begin{array}{l}0.0088^{*} \\
(6.8057)\end{array}$ & $\begin{array}{l}0.033^{\star} \\
(8.6067)\end{array}$ & 0.94 & 0.93 & 209.77 \\
\hline
\end{tabular}

Source: Computed from field survey, 2007 * Significant at $1 \%$ level

Table 3: Estimated Elasticities of Production (Ep), Average Product (AP), Marginal Product (MP), Marginal Value Product(MVP),

\begin{tabular}{|l|l|l|l|l|l|l|l|}
\hline Variables & EP & AP & MP & MVP & $P$ & AEL & Inference \\
\hline Fertilizer $\left(X_{1}\right)$ & 0.009 & 116.74 & 1.04 & 37.40 & 12 & 3.12 & $\begin{array}{l}\text { Under- } \\
\text { utilized }\end{array}$ \\
\hline Cassava $\left(X_{2}\right)$ & 0.08 & 12.63 & 1.01 & 108.33 & 100 & 1.08 & $\begin{array}{l}\text { Under- } \\
\text { utilized }\end{array}$ \\
\hline Labour $\left(X_{3}\right)$ & 0.08 & 74.83 & 6.05 & 217.60 & 153 & 1.42 & $\begin{array}{l}\text { Under- } \\
\text { utilized }\end{array}$ \\
\hline $\begin{array}{l}\text { Other operating } \\
\text { expenses }\left(X_{4}\right)\end{array}$ & 0.07 & 14.57 & 1.02 & 106.30 & 18.5 & 5.75 & $\begin{array}{l}\text { Under- } \\
\text { utilized }\end{array}$ \\
\hline
\end{tabular}

Source: Field survey, 2007

\section{COMCULSION}

The results of this study showed that sole cassava production at small -scale farmers' level was profitable. The production function analysis revealed that fertilizer and labour were inefficiently used. The marginal value producis of fertilizer; cassava stem, labour and other operating expenses were N37.40, N10833, N217.66 and N106.30 respectively, there existed allocative inefficiency. There is a high potential for famers to increase their yields and income by improving on production efficiency and adopting new technologies. 


\section{RECOMMENDATIOMS}

Having noted some of the constraints against effective cassava production in Akwa ibom State, this paper makes the following recommendations;

(i) Famers should increase their yields and income by improving on production efficiency and adopting new technologies. It is therefore recommended that extension agents should train iamers on the adoption of new technologies.

(ii) Extension agents should encourage cassava farmers to use labour saving tools / machines for cassava production to allow for optimum labour utilization in fam operations

(iii) Capacity building of famners through regular training on application of recommended rate of fertilizer that would help in ensuring profitable retums

\section{REPERENCES}

Aboje, P., 2006. Cassava Chips Production and Export .Daily Sun, Monday, December 18, (2006): p 39

Abott, J. C. and Makeham, J. P., 1979. Agricultural Economics and Marketing the Tropics. Published by Longman Group UK Limited. England Pp1-161

Adinya, 1. B., 2001. Factors influencing Labour Utilization in Small-Scale Cassava Production: A Case study of Uyo Agricultural Zone of Akwa thom State. MSC. Thesis Unpublished, University of Uyo, Akwa Ibom State.pp1-104.

Adinya, I. B., Ajayi, S. and Idiege D. A., 2006. Economic Analysis of cassava production in Akwa lbom State. Jounrnal of Agiriculture, Forestry and Social Sciences. Vol. 4 No2

Alimba, J. O. and Ezinwa, J. O., 2001. Resource productiviły of yam- Based mixed cropping system of Anambra State, south Eastern Nigeria. Joumal of the science of Agriculture, food Technology and Environment October (2001) pp 63.67

Awoke, M. U. and Obeta, M. E, 1998. Economic Analysis of small- scale Yellow pepper Enterprises in Nsukka Area. Cital Journal $2(5): 40-49$.

Chikwendu, D. O. and Amos ,T. T., 1998..Economics of Maize production in three villages of Niger State. Nigeria. Joumal of Agricultural Technology, 6 (2): 12-18.

Delgado, C. L. Hopkins, J. and Kelly, V., 1994. Agricultural Growth Linkages in Sub-Saharan African:Syhtesis. In : Proceedings of a Workshop on Agricullural Growth Linkages in Sub- Saharan African, Internal Food Policy Research, Institute, Washington p22-26.

Duff, G. E., 1994. The Economics of Cassava Production :A Case Study of Nsit tbom Local Government Area . B.SC. Thesis Unpublished, University of Calabar, Calabar, Nigeria. P .26.

Emokaro, C. O. and Erhabor, P. O., 2005. Efficiency of Resource Use in Cassava Production in Edo State, Nigeria. Joumal of Agriculture, Forestry and the Social Sciences, 3(2): 14-23.

Farrel, M. J., 1984. The measurement of Production efficiency. Journal of Royal Statistic Society Series A120 Part3, 253-281.

Fertilizer Use and Management Practices for Crops in Nigeria, 1989. Published by the Fertilizer Procurement and Distribution
Division of the Federal Ministry of Agriculture, Water Resources and Rural Development, Lagos, ppo73-74

Herbert, 8., 2005. Production Function Analysis of cassava Based Cropping System in River State. Nigeria dournal of Agriculure. Forestry and The Social Sciences, $3(2): 59-57$

Ngaba, R. R. and Lee, J. S., 1979. Fermentation of Cassava (Manihot esculenta Crantz). American Joumal Food Sciences. A4: $1570-1571$

Nsikak-Abasi, A. E., औ. U. Edet and Awoyemi, T. T., 2005 Measuring Technical Efticiency of Urban Fams in Uyo Metropolis. Global Journal of Agricultural Sciences, $4(1): 91-95$

Nweke, F. I. and Winch F.E. 1979. Bases of Farm Resource Allocation in small holder cropping systems of South Eastern Nigeria : A case study of Awka and Abakaliki villages, international Institute of Tropical Agriculture, lbadan Discussion paper4/80.

Nweke, F. I., Spencer, D. S. C. and Lynam, J. K., 2002. The Cassava Transformation :Africa's Best-Kept Secret Michiggan State University Press, East Lansing Michigan, U.S.A.pp1-231.

Oguniowara, O., Essang S. M. and Olayide S. O., 1974 Resource Productivity in Traditional Agriculture A case study of Pour Agricultural Divisions in Kwara Slate of Nigeria. Journal of Rural Economics and Development, $49(4): 119-132$

Ogungbile, A. O. and Olokosi, J. O., 1990. An Overview of the problems of the Resource. Poor Farmers in Nigeria Agricultures. In: Olokosi, d. O. and Ogungbile A.O. (Eds) Appropriate Agricultural Technologies for Resources- Poor Famers. The Nigeria National Farming Systems Research Network, zaria p311

Ogungbile, A. O. and S. A.Sanni, 1991. Resource Productivity and Technological Change in Cotton Production in Kastina State. Niggeria Joumal of Rural Economy and Sociely, 1(1):77-85.

Okafor, N. 1977. Micro-organisms Associated with Cassava Fermentation for Garri Production. Journal of Applied Bact $42: 279-284$

Olayide, S. O. and Heady, E. O., 1982. Introduction to Agricultural Production Economics. Ibadan Universify Press, lbadan pp.1-56.

Osuji, L. O., 1978. Resource Productivity in Traditional Agriculture: A Case Study of Selected Villages in Imo State. Unpusblished Ph.D Thesis Department Economics, University of Ibadan, Nigeria.

Upton, M., 1973. Farm Management in Africa .Oxford University Press, London, pp1-35.

Upton, M., 1976. Agriculitural Production Economics and Resource Use. Oxford University Press. London.pp\%. 20

Uyo Local Government Area Information Brochure, 1992 Yotopoulos, P. A., 1967. Allocative Efficiency in Economic Development. Constantinidis, Athens . Greece, pp $1-313$ 